\title{
Kouvola Housing fair NZEB houses energy, cost and carbon analyses
}

\author{
Kaiser Ahmed ${ }^{1,2^{*}}$, Hatef Hajian ${ }^{1}$, Tero Hasu ${ }^{3}$, and Jarek Kurnitski ${ }^{1,4}$ \\ ${ }^{1}$ Aalto University, Department of Civil Engineering, Finland \\ ${ }^{2}$ Granlund Consulting Oy, Finland \\ ${ }^{3}$ Kouvola Innovation Oy, Finland \\ ${ }^{4}$ Tallinn University of Technology, Department of Civil Engineering and Architecture, Estonia
}

\begin{abstract}
Building energy efficiency, construction cost, life cycle cost, and carbon emission are the best interests of users, owners and different vendors. This study assessed the energy performance (EP) related investment and operational energy cost of Kouvola housing fair NZEB. Data from 12 new detached houses were collected, which fulfilled the energy certificate class of B according to the Finnish nearly zero energy building (NZEB) regulation. Besides, emission from building materials, construction and energy use during 50 years of one model building were estimated, aiming to compare the life cycle emission from wooden building, insulated concrete building, blockhouse and log house. The results showed that the total construction cost was independent to EP-value and even had a slightly negative correlation to the EP-value. The average EP-value of 12 buildings was slightly higher than that of buildings in Tampere housing fair 2012, which showed no improvement of nearly zero energy building (NZEB) guidelines since 2012. Energy performance related cost dependency in specific cost categories was shown so that EP-value improvement by 40 units increased less than $2 \%$ of construction cost. Electricity had a significant contribution to $\mathrm{CO}_{2}$ emission while local district heating was based on renewables. Material emissions contribution was $32-48 \%$ of total emissions, and wooden buildings showed lower carbon footprint compared to other building structures.
\end{abstract}

\section{Introduction}

Energy performance is generally linked to the amount of energy required in order to have sufficient environmental standards and to accomplish the building purpose[1]. Lowering energy use is a well-known and pressing issue, as several reports have emphasized the effect of energy consumption on climate change [2]. Kurnitski [3] listed the common measures for achieving the NZEB targets for non-residential buildings such as balanced heat recovery ventilation system, façade with highly utilization of daylight, efficient HVAC and so on.

The analysis of energy usage during the operating process may promote the renovation of the current building stock by retrofits and behavioural change programs[4]. Designing residential buildings that use less operational energy will lead to a decrease in energy demand. By fact, though, that is not always what has been found [1]. Operating energy is, in theory, equal to the operational carbon footprint (OCF) of the energy consumption, which may, therefore, be replaced by one another; however, the bulk of attempts to reduce the operational carbon footprint (OCF) have a negative impact on the embodied carbon footprint (ECF) [5]. Kurnitski [6] listed the common measures for achieving the nearly zero energy building (NZEB) targets for nonresidential buildings such as balanced heat recovery ventilation system, façade with highly utilization of daylight, efficient HVAC and so on.

Reducing the need for balance between the building efficiency and investment cost is a crucial factor in ensuring resilience in the built environment [7]. Although it is obvious that lower electricity consumption contributes to financial savings and lowered pollution, this cannot be considered as a certain model [8]. Additional investment costs of two apartment buildings in Estonia were increased by $4-7 \%$ when EP value shifted from $110 \mathrm{kWh} / \mathrm{m}^{2}$ a close to NZEB requirements of $100 \mathrm{kWh} / \mathrm{m}^{2} \mathrm{a}$ [9]. Agostino and Parker (2018) [10] showed the fulfilment of NZEB benchmark at the lowest cost in 14 European cities. The model developed in [10] explained the requirements of NZEB construction and how the NZEB design principle and unit cost were varied considerably by climate. Meeting a lower energy requirement without compromising for comfort could entail higher investment, which can often outweigh subsequent financial savings. Therefore, seeking approaches that achieve adequate efficiency and cost-optimal outcomes requires tackling these goals concurrently [11].

The energy efficiency of the building is directly related to the resulting greenhouse gas emissions over its life cycle. Lolli et al. [12] showed the largest reduction of GHG emissions due to the replacing of concrete elements by cross laminated timber in NZEB student housing and NZEB residential buildings. Moreover, increasing the wood usages could reduce the carbon emission from material manufacturing by $20 \%$ compared to brick, aluminium, steel and concrete in New Zealand building industry [13]. The key sources of building-based greenhouse gas pollution are the utilization of the energy and material supplies used for

\footnotetext{
* Corresponding author: kaiser.ahmed@aalto.fi
} 
building, service, repair and renovation and, ultimately, for end-of-life operations [14]. IEA EBC Annex 57 specifies that the embodied $\mathrm{CO}_{2}$ equivalent is the total quantity of greenhouse gasses emitted through directly and indirectly processes relevant to the development, repair and end-of-life of the structure [15].

Towards a sustainable building environment poses a range of obstacles, one of which is to reach acceptable energy efficiency or pollution rates while staying economically beneficial [11]. Multi-objective optimization makes it easier to find the most suitable options where there are several evaluation requirements and has been commonly used as a sustainability analysis method in the built environment [16].

This study collected detailed information of 12 NZEB detached houses in Kouvola housing fair, aiming to assess construction cost, life cycle cost, and operational carbon emission. Besides, carbon footprint of materials for wooden building, insulated concrete building, blockhouse and log house were analysed for a model building. The findings provide actual construction information of NZEB detached houses, which would be in the interests of different vendors and building professionals.

\section{Methods}

Kouvola housing fair district had thirty-one residential buildings which were situated nearly close to each other. Data were from 12 new detached houses. Other buildings were either renovated houses or multi-family apartment buildings, which were excluded from the study as not representative for new NZEB houses. All studied detached houses fulfilled the EP-value requirement of NZEB, which depends on the size of the house. This study showed the investment and operational energy cost for this district. Besides, life cycle assessment (LCA) was estimated of the same building with four different building structures, namely wooden building, insulated concrete building, blockhouse and log house. This LCA included the emission from building materials, construction and energy use during 50 years.

\subsection{District buildings' description}

The district buildings are located in the city of Kouvola, about $12 \mathrm{~km}$ to south-East from the city centre. This location is outside of the city centre in a suburb. All buildings were low-rise detached houses, which were privately owned and mostly prefabricated in the factory. All buildings were classified as "Small residential building". The total heated areas of the building were varied from 86 to $210 \mathrm{~m}^{2}$. None of the houses had achieved the top Finnish energy certificate class A, which represents beyond NZEB level as NZEB corresponds to class B. Building location is shown in the following Figure 1. The cost was estimated for building no $2,3,4,5,13,14,16,17,21,22,23$, and 32 .

The $U$ value of external walls was varied only slightly from 0.16 to $0.17 \mathrm{~W} / \mathrm{m}^{2} \mathrm{~K}$. The roofs were highly insulated, which gives a U-value of 0.08 to $0.09 \mathrm{~W} / \mathrm{m}^{2} \mathrm{~K}$. The roof structure generally consists of steel metal plate, wooden truss, joist, thermal insulation, vapour barriers and cladding. The designed insulation values of the ground floor were varied from 0.11 to $0.17 \mathrm{~W} / \mathrm{m}^{2} \mathrm{~K}$, which were achieved by using a floor covering, concrete slab, insulation and gravel layer. Besides, U-value for windows were varied from 0.84 to $1.0 \mathrm{~W} / \mathrm{m}^{2} \mathrm{~K}$, and $\mathrm{G}$ values were within the range of 0.47 to 0.64 . Tripleglazed windows with low-e coating were used.

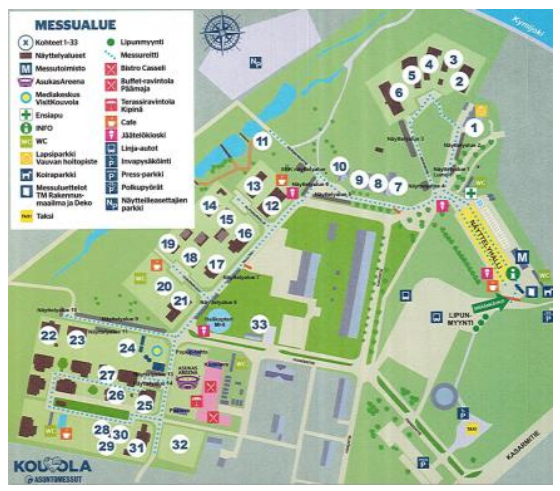

Fig. 1. Location of buildings.

Airon Haave detached house, used for LCA calculation, was one of the 12 houses (Building no 04), as shown in Figure 2. The total heated area and volume were $155.6 \mathrm{~m}^{2}$ and $485 \mathrm{~m}^{3}$, respectively. External walls had mineral wool insulation, which gave a U-value of $0.16 \mathrm{~W} / \mathrm{m}^{2} \mathrm{~K}$. The roof was insulated with at least 500 $\mathrm{mm}$ of mineral wool insulation to reach the design Uvalue of $0.08 \mathrm{~W} / \mathrm{m}^{2} \mathrm{~K}$. The designed insulation value of the ground floor was $0.14 \mathrm{~W} / \mathrm{m}^{2} \mathrm{~K}$. U-value for windows and doors were $1.0 \mathrm{~W} / \mathrm{m}^{2} \mathrm{~K}$, respectively. Besides, it had triple-glazed windows with low-e coating and $G$ value of 0.64 . The building had a pile foundation.

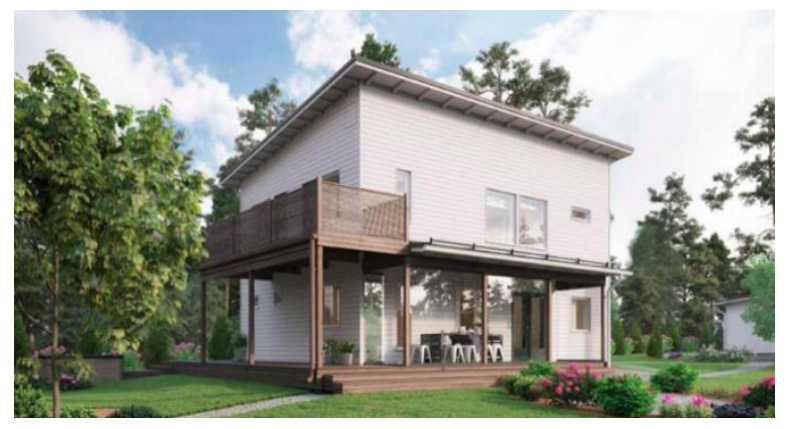

Fig. 2. Airon Haave house used for LCA analyses.

\subsection{Technical building systems description}

All buildings had mechanical ventilation systems with heat recovery ventilation units. The temperature ratios of eight buildings were 70 to $77 \%$ and other three buildings had a low temperature ratio of $55 \%$. Specific fan powers were within the range of 1.16 to 1.8 $\mathrm{kW} /(\mathrm{m} 3 / \mathrm{s})$. District heating was used as a heat source in 9 buildings. Three buildings out of 12 had air to water heat pumps and fireplace. In all building, underfloor heating was used. Ventilation units had electrical supply 
air reheating coils except one building where hydronic heating coil was used.

The temperature ratio in Airon Haave detached house was $79 \%$, and specific fan power was 1.8 $\mathrm{kW} /\left(\mathrm{m}^{3} / \mathrm{s}\right)$. Besides, it had balanced ventilation system of $0.06 \mathrm{~m}^{3} / \mathrm{s}$ nominal air flow rate, and the electric reheating coil of the supply air. The extract air temperature limit of the counter-crossflow plate heat exchanger was $5^{\circ} \mathrm{C}$ and floor heating system efficiency of $94 \%$ in energy calculation.

\section{Results and analysis}

\subsection{Energy performance}

EP values were quite close to the minimum requirement for all buildings, which depends on the size of the house. All buildings achieved energy certificate class B, Figure 3. The average EP-value was $101 \mathrm{kWh} / \mathrm{m}^{2} \mathrm{a}$ (primary energy per heated floor area), which was slightly higher than the estimated average EP value at the Tampere 2012 housing fair. Moreover, thermal insulation level was close to the minimum reference values in the regulation. None of the houses did use highperformance thermal insulation according to a voluntary specification for highly insulated building in the regulation, Figure 4.

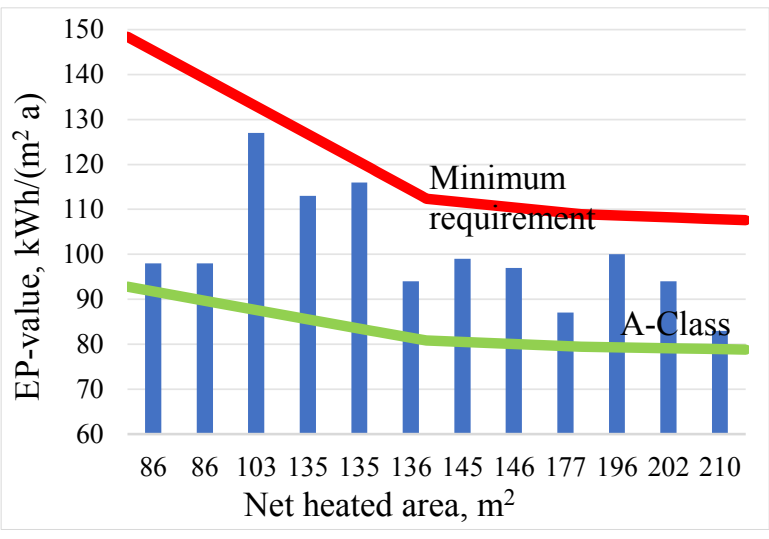

Fig. 3. EP-value in 12 detached houses.

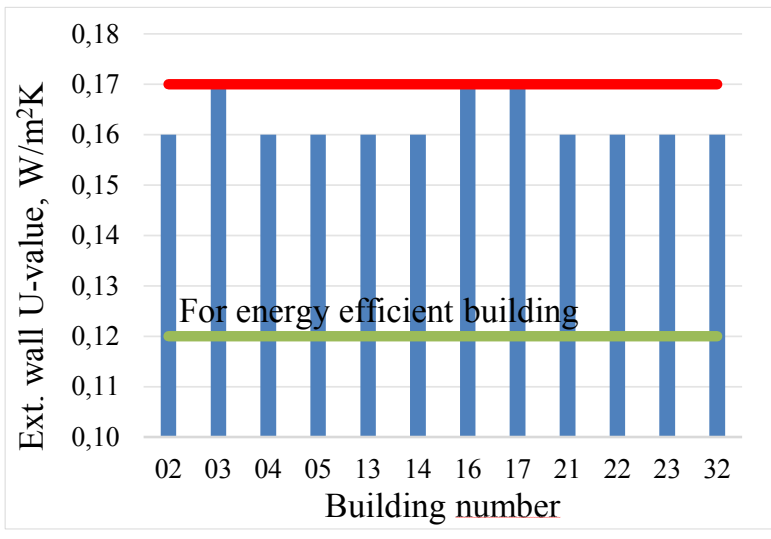

Fig. 4. U value of external wall for 12 detached houses.

\subsection{Investment cost analysis of district buildings}

The construction cost correlation with EP-value is shown in Figure 5. The figure shows that the EP-value has had no impact on the construction cost. Even a slightly negative correlation is found, showing that more energy-efficient buildings have been cheaper at the Kouvola housing fair. This cost only included the prefabricated building cost and the cost for erected on the site. Foundation and yard cost were not included.

The total costs and unit cost of the district buildings are shown in Table 1. For each building, all costs were tabulated under six different sections, namely building, HVAC installation, El installation, IT \& automation, renewable energy installation and other costs. Building cost included excavation, foundation, building structure, canopies, windows, doors, basic furniture, standard equipment, fireplace, yard, coverings for traffic areas, plants and site cleaning. Besides, the cost for HVAC installation included heating, domestic hot water sewerage, plumbing fixture, rainwater, air conditioning system. Electrical component related cost is shown under El installation, whereas communication components related cost was tabulated under the section of IT \& automation. The cost of real estate and projectrelated tasks are considered a common task. This cost price did not include the profit of the construction company. Besides, VAT was not included into this cost. Moreover, the unit cost was estimated based on the gross internal area (GIA), i.e. heated area.

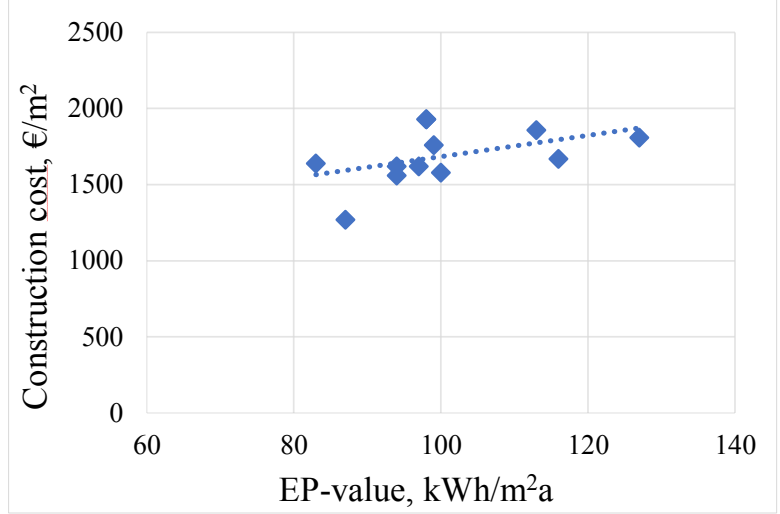

Fig. 5. Dependency of construction cost on EP-value (foundation and yard cost not included) [17].

Energy performance related additional cost was calculated relative to electrical heating and minimum reference U-values specified in the regulation. Energy performance related additional cost shown in Figure 6 indicates that an energy performance improvement of 40 units of EP-value has additional construction cost less than $30 € / \mathrm{m}^{2}$. The additional energy performance related cost was small compared to an average construction cost of $1700 € / \mathrm{m}^{2}$ (average of ready-to-move price not including foundation and yard cost). 


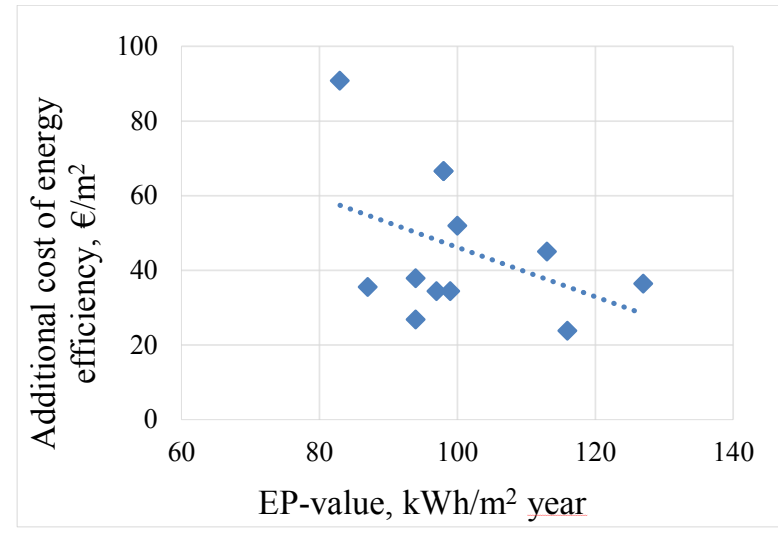

Fig. 6. Additional energy performance related construction cost as a function of EP-value [17].

\subsection{Operational cost analysis of district buildings}

The yearly operational energy cost for all buildings is shown in Figure 7. Only two small semi-detached dwellings had achieved low energy costs of less than

Table 1. The detailed cost segments for district buildings [17].

\begin{tabular}{|l|r|r|r|r|r|r|r|r|r|r|r|r|}
\hline Building no & 2 & 3 & 4 & 5 & 13 & 14 & 16 & 17 & 21 & 22 & 23 & 32 \\
\hline Common costs, $€ / \mathrm{m}^{2}$ & 272 & 258 & 276 & 292 & 259 & 302 & 302 & 302 & 272 & 267 & 294 & 310 \\
\hline Building, $€ / \mathrm{m}^{2}$ & 1829 & 1758 & 1814 & 2319 & 1834 & 1989 & 1639 & 1639 & 1856 & 1743 & 1782 & 2175 \\
\hline HVAC installations, $€ / \mathrm{m}^{2}$ & 241 & 223 & 221 & 257 & 214 & 221 & 278 & 278 & 213 & 211 & 207 & 245 \\
\hline El-installations, $€ / \mathrm{m}^{2}$ & 142 & 142 & 142 & 142 & 142 & 142 & 142 & 142 & 142 & 142 & 142 & 142 \\
\hline IT and automation, $€ / \mathrm{m}^{2}$ & 9 & 9 & 9 & 10 & 9 & 10 & 10 & 10 & 10 & 10 & 10 & 10 \\
\hline $\begin{array}{l}\text { Other installations, PV, } \\
€ / \mathrm{m}^{2}\end{array}$ & 0 & 0 & 0 & 0 & 0 & 0 & 0 & 0 & 0 & 0 & 0 & 0 \\
\hline Total cost,$€ / \mathrm{m}^{2}$ & 2493 & 2389 & 2462 & 3019 & 2459 & 2663 & 2371 & 2371 & 2492 & 2372 & 2434 & 2882 \\
\hline
\end{tabular}

$1,000 € / a$. Energy costs do not show a clear dependence on the size of the house but rather on technical solutions; the largest house had an annual energy cost of well over $2000 € / \mathrm{a}$.

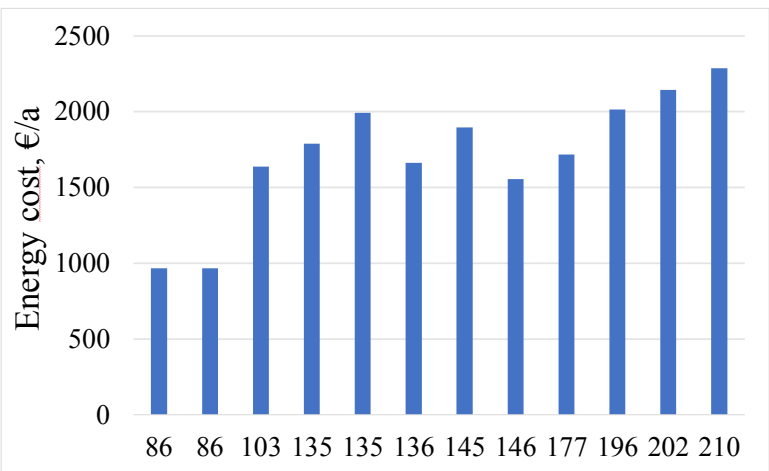

Heated floor area, $\mathrm{m}^{2}$

Fig. 7. Energy cost of district buildings.

\subsection{Operational energy and $\mathrm{CO}_{2}$ emissions of the district}

This study summarized the operational energy and $\mathrm{CO}_{2}$ emission of the district. Eight buildings out of twelve had district heating system. Other buildings had either electric heating or wooden chips heating. Furthermore, $\mathrm{CO}_{2}$ emission from each building was different due to variant energy source and consumption. The delivered energy and $\mathrm{CO}_{2}$ emission of 12 buildings per unit area are shown in the following figures.

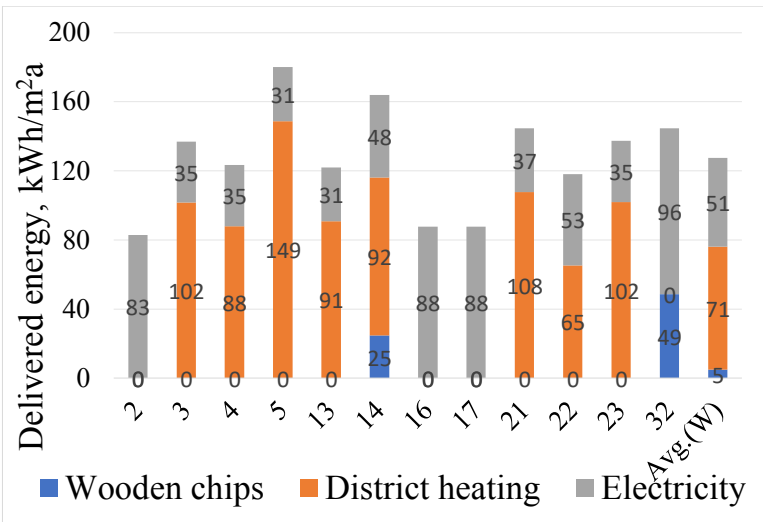

Fig. 8. Delivered energy of district buildings.

\subsection{Comparison of unit cost}

This study investigated the cost data of 12 buildings where the unit cost is varied from 2371 to $3019 € / \mathrm{m}^{2}$. The detailed cost information of building 5 and 16 are shown in Table 2, which had the highest and lowest investment cost, respectively. Beside, the most representative cost data (building 21) are shown in Table 2. The number mentioned in the table has shown the probable cause of unit cost variations'. 


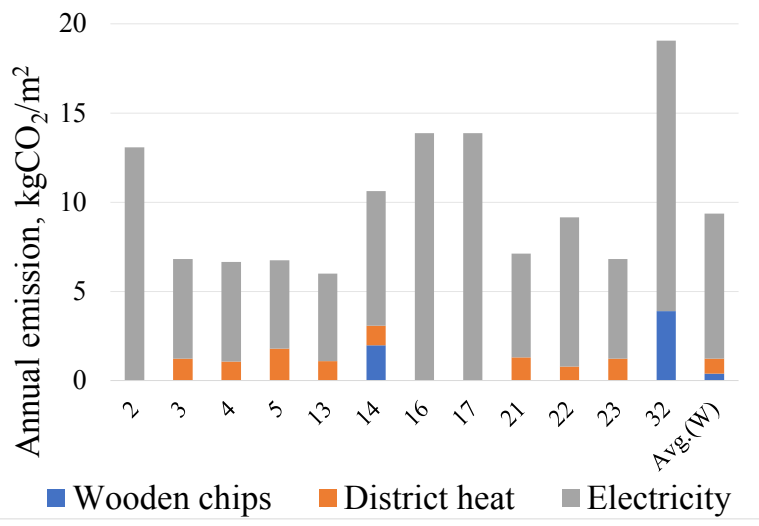

Fig. 9. $\mathrm{CO}_{2}$ emission of district buildings.

This study also compared the core construction cost such as foundation, ground floor, intermediate floor, roof, and external wall of 12 buildings. Eight buildings were single floor building whereas four building were double storied building. According to the building plan, most of the buildings were nearly rectangular and some of those had multiple wings. Besides, the floor to ceiling height, floor to roof height, window wall ratio, and floor area were different according to the drawings. Also, single sloped, double sloped and variable sloped roof were available. Thus, it was complicated to figure out the actual reasons of cost variations. However, some common correlation were observed. For instance, building with more regular shape (less building corner) had lowest foundation cost compared to the building with irregular shape. Besides, double storied building had higher foundation cost $\left(125-141 € / \mathrm{m}^{2}\right.$ of ground floor area) compared to the single story building (98-122 $€ / \mathrm{m}^{2}$ of ground floor area). Similar observation also found for ground floor but the range of unit cost was bigger due to having different floor finishing materials. The unit costs of ground floor for double storied buildings were varied from 107 to $202 € / \mathrm{m}^{2}$.

On the other hand, the unit cost of roof for single floor buildings seemed nearly same $\left(80-81 € / \mathrm{m}^{2}\right.$ of roof area) but higher cost data were found for double storied buildings (86-108 $€ / \mathrm{m}^{2}$ of roof area) because of high installation costs. Furthermore, unit costs of external wall for four single floor buildings were nearly same (171-174 €/m² of net heated area).

Table 2: Detailed cost comparison [17].

\begin{tabular}{|l|r|r|r|}
\hline${ }^{2}$ Building number & 5 & 16 & 21 \\
\hline Gross internal area (GIA), $\mathrm{m}^{2}$ & 144 & 93 & 145 \\
\hline Building related cost & \multicolumn{3}{|c|}{ Unit cost, $€ / \mathrm{m}^{2}$} \\
\hline Land (e.g. Clearing) & 36 & 32 & 32 \\
\hline $\begin{array}{l}\text { Digging, filling (inside \& } \\
\text { outside) }\end{array}$ & 115 & 107 & 104 \\
\hline $\begin{array}{l}\text { Ground parts (quarrying, piling, } \\
\text { special fillings) }\end{array}$ & 0 & 0 & 0 \\
\hline $\begin{array}{l}\text { b Coverings (traffic areas, lawns } \\
\text { \& plantings) }\end{array}$ & $\mathbf{1 7 4}$ & $\underline{\mathbf{8 1}}$ & $\underline{\mathbf{1 7 2}}$ \\
\hline Area services & 0 & 0 & 0 \\
\hline cYard storage & $\mathbf{2 2 6}$ & $\mathbf{0}$ & $\underline{\mathbf{1 4 2}}$ \\
\hline $\begin{array}{l}{ }^{\mathrm{d}} \text { Canopies (terraces, porches, } \\
\text { balconies) }\end{array}$ & $\mathbf{4 9 6}$ & $\mathbf{1 4 7}$ & $\mathbf{7 0}$ \\
\hline Foundation & 98 & 122 & 113 \\
\hline
\end{tabular}

\begin{tabular}{|l|r|r|r|}
\hline Ground floor & 148 & 169 & 168 \\
\hline Internal floor & 0 & 0 & 0 \\
\hline Roof & 80 & 81 & 81 \\
\hline Exterior walls & 163 & 172 & 187 \\
\hline${ }^{e}$ Windows \& exterior doors & $\mathbf{1 1 6}$ & $\mathbf{1 3 0}$ & $\mathbf{1 4 6}$ \\
\hline Roof top \& windows & 162 & 166 & 158 \\
\hline Internal wall & 131 & 116 & 123 \\
\hline${ }^{\text {S}}$ Space surface & $\mathbf{1 9 7}$ & $\mathbf{1 4 4}$ & $\underline{\mathbf{1 7 6}}$ \\
\hline $\begin{array}{l}\text { Equipment: solid furniture, } \\
\text { closets \& accessories }\end{array}$ & 117 & 126 & 122 \\
\hline gStandard Equipment & $\underline{\mathbf{3 0}}$ & $\underline{\mathbf{4 6}}$ & $\mathbf{3 0}$ \\
\hline${ }^{\text {h} F i r e p l a c e s ~ a n d ~ c h i m n e y s ~}$ & $\mathbf{3 0}$ & $\mathbf{0}$ & $\underline{\mathbf{3 0}}$ \\
\hline Systems related cost & Unit cost, €/m ${ }^{2}$ \\
\hline${ }^{i}$ Heating system & $\underline{\mathbf{8 1}}$ & $\underline{\mathbf{1 2 1}}$ & $\underline{\mathbf{7 1}}$ \\
\hline Hot water system & 15 & 15 & 15 \\
\hline Sewage system & 5 & 5 & 5 \\
\hline${ }^{j}$ Plumbing fixtures & $\underline{\mathbf{5 7}}$ & $\underline{\mathbf{2 9}}$ & $\underline{\mathbf{3 4}}$ \\
\hline Rainwater system & 29 & 28 & 27 \\
\hline Central cleaning system & 0 & 0 & 0 \\
\hline Air conditioning systems & 69 & 80 & 61 \\
\hline $\begin{array}{l}\text { Electrical components: electrical } \\
\text { systems }\end{array}$ & 142 & 142 & 142 \\
\hline $\begin{array}{l}\text { Communication components: } \\
\text { information systems }\end{array}$ & 10 & 10 & 10 \\
\hline
\end{tabular}

a) Building 5: Highest cost; Building 16: Lowest cost; Building 21: Close to average unit cost

b) This type of cost depends on end-users, which can be minimized. Such type of facility does not belong to the building itself, but it belongs to the broader property area.

c) This type of facility may require if the user has a larger yard for keeping daily outdoor usage staff, i.e. gardening staff.

d) This type of cost depends on end-users, which can be minimized or omitted. Such type of facility is not the mandatory cost, but it increases the user comfort and sights.

e) It depends on the architectural design. In general, window wall ratio is higher in smaller building compare to the larger building that may increase the unit cost in smaller buildings.

f) The surface finishing material also user-defined, and the unit cost may vary based on the selection of the materials.

g) The total cost of standard equipment is equal for both cases. If we express the total cost as a unit cost, then it shows a higher unit cost for smaller building compared to the larger building.

h) Fireplaces may be omitted if building has a good heating system. i) Energy connection cost is not dependable on the GIA. Unit cost corresponding to the heating facility may higher in the smaller area compare to the larger area. However, piping amounts may increase the total cost, which depends on the net heated area.

j) The larger building has two bathrooms $\left(7 \mathrm{~m}^{2}\right)$ which requires two sets of plumbing equipment. Besides, larger space encourages to fit additional WC seats.

Building 21 had highest unit cost of external wall (187 $€ / \mathrm{m}^{2}$ of net heated area), which was found as the most irregular shaped building with two wings, nonuniform building height. The floor to ceiling and floor to roof heights were $2.678 \mathrm{~m}$ and $5.107 \mathrm{~m}$ for one wing and $4.138 \mathrm{~m}$ and $6.027 \mathrm{~m}$ for another wing, respectively. On the other hand, building 23 had lowest unit cost of external wall (143€/m² of net heated area), which was rectangular shaped building and had almost uniform building height. The floor to ceiling and floor to roof heights were $2.5 \mathrm{~m}$ and $5.017 \mathrm{~m}$, respectively.

\subsection{Emission comparison for different building materials}


This study showed the LCA of Airon Haave building for four different structural material solution such as wooden building, insulated concrete building, blockhouse and log house, as shown in Figure 10. The results showed how building materials had an impact on the emission of $\mathrm{CO}_{2}$. Log house emitted lower $\mathrm{CO}_{2}$ among four different structural types, whereas the blockhouse emitted the maximum amount.

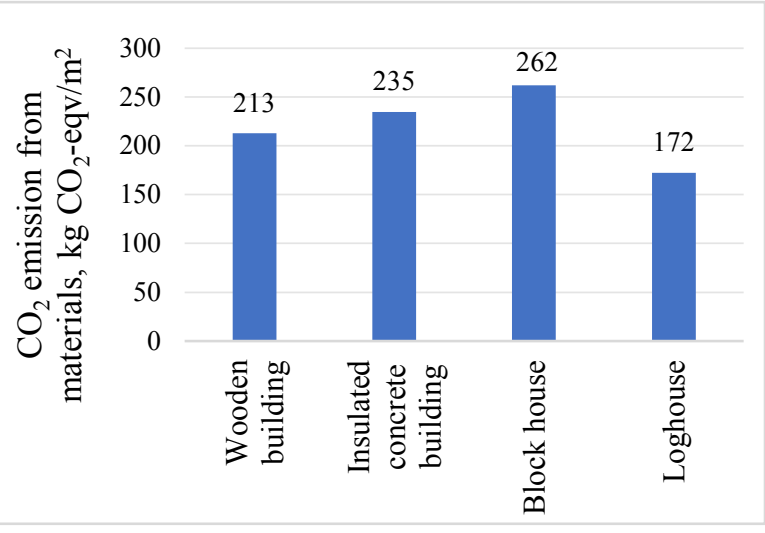

Fig. 10. The carbon footprint from different building structures (transportation emission and $\mathrm{CO}_{2}$ storage are not included).

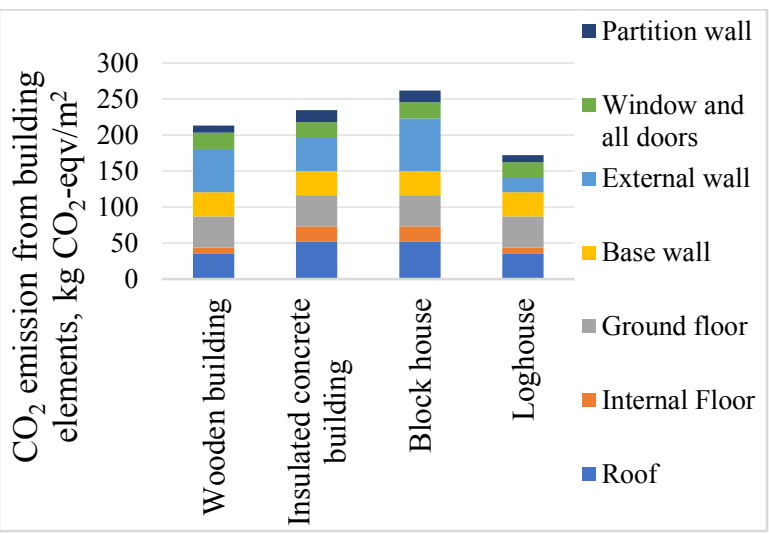

Fig. 11. $\mathrm{CO}_{2}$ emission from different building elements.

Low $\mathrm{CO}_{2}$ emissions were generated during transportation from the factory to onsite. Wooden building, insulated concrete building, blockhouse and $\log$ houses were emitted 20, 43, 43 and $20 \mathrm{~kg} \mathrm{CO}_{2-}$ eqv $/ \mathrm{m}^{2}$ during transportation, which is not included in Figure 10. Besides, carbon storage of wooden building, insulated concrete building, blockhouse and log house were $180,54,54$, and $259 \mathrm{~kg} \mathrm{CO}$-eqv $/ \mathrm{m}^{2}$ respectively, which are also not included in Figure 10. Carbon is stored in the wood during its growth. Wooden building materials store a large amount of carbon until the material rot or burns. In this way, it reduces the $\mathrm{CO}_{2}$ emission. In addition, carbon footprints at building element levels are shown in Figure 11. External walls had larger contribution of $\mathrm{CO}_{2}$ emission for all structural material solutions except loghouse. Besides, floor finishing material had second largest contribution of $\mathrm{CO}_{2}$ emission, which followed by roof, base wall, window and all doors.

The total carbon emissions for different building structures are shown in Figure 12. The log house's carbon balance was negative due to the ample storage of carbon. Besides, total $\mathrm{CO}_{2}$ emission of a wooden house was also significantly lower compared to the insulated concrete building and the blockhouse. Thus, wooden buildings are considering the most environment-friendly buildings if we account the carbon storage.

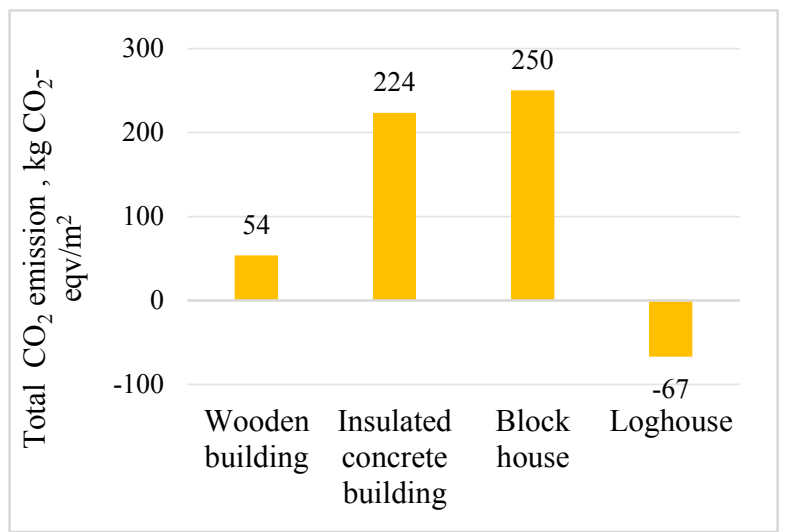

Fig. 12. The sum of $\mathrm{CO}_{2}$ emissions and carbon storage of building structures.

According to EPC, annual electricity and district heating were 5506 and $13699 \mathrm{kWh} / \mathrm{a}$, respectively. The detailed energy segments are shown in Table 3.

Table 3: Detailed of energy use.

\begin{tabular}{|c|c|c|c|c|}
\hline \multirow[b]{2}{*}{ Energy details } & \multicolumn{2}{|c|}{$\begin{array}{c}\text { Delivered } \\
\text { energy }\end{array}$} & \multicolumn{2}{|c|}{$\begin{array}{c}\text { *Primary } \\
\text { energy }\end{array}$} \\
\hline & 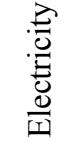 & 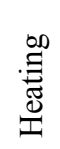 & 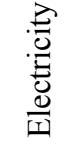 & 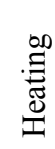 \\
\hline $\begin{array}{l}\text { Space heating, } \\
\mathrm{kWh} / \mathrm{m}^{2} \mathrm{a}\end{array}$ & 0 & 57 & 0 & 29 \\
\hline $\begin{array}{l}\text { Ventilation air heating, } \\
\mathrm{kWh} / \mathrm{m}^{2} \mathrm{a}\end{array}$ & 8.1 & 0 & 9.7 & 0 \\
\hline $\mathrm{DHW}, \mathrm{kWh} / \mathrm{m}^{2} \mathrm{a}$ & 0 & 32 & 0 & 16 \\
\hline Fan \& pump, kWh/m²a & 6.3 & 0 & 7.6 & 0 \\
\hline $\begin{array}{l}\text { Lighting \& appliances, } \\
\mathrm{kWh} / \mathrm{m}^{2} \mathrm{a}\end{array}$ & 21 & 0 & 25.2 & 0 \\
\hline Total, $\mathrm{kWh} / \mathrm{m}^{2} \mathrm{a}$ & \multicolumn{2}{|c|}{124} & \multicolumn{2}{|c|}{87} \\
\hline
\end{tabular}

As this is a residential building, the LCC of energy was estimated for 50 years. Besides, the nominal interest rate, inflation and escalation of energy price were assumed of $4 \%, 2 \%$ and $1 \%$, respectively. The unit price of electricity and district heating were considered of $0.12 € / \mathrm{kWh}$ and $0.09 € / \mathrm{kWh}$, respectively (VAT 24\%). The electricity and district heating for 50 years were estimated of 275.25 and $684.95 \mathrm{MWh}$, respectively. Besides, the net present value of the operational energy cost of 50 years was $76020 €$ (VAT 24\%). 


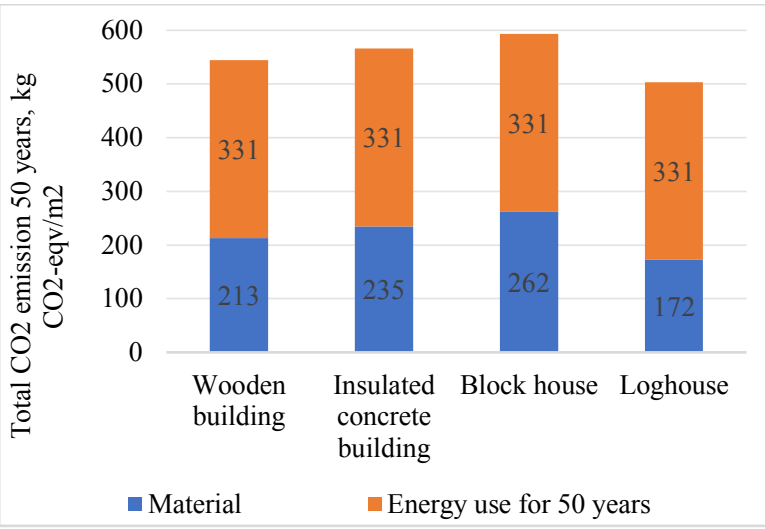

Fig. 13. The total $\mathrm{CO}_{2}$ emission from building materials and operational period of 50 years.

In Kouvola, $\mathrm{CO}_{2}$ emissions for producing district heat and electricity were 11.75 and $158 \mathrm{kgCO}_{2} / \mathrm{MWH}$, respectively. The $\mathrm{CO}_{2}$ emission for the production of district heat in Kouvola was very low due to introducing renewable heat, which had a share of $94 \%$. Besides, natural gas had a share of $6 \%$ only. Results found that the operational emissions were dominated one over construction one. The materials' $\mathrm{CO}_{2}$ emissions were $39 \%, 41 \%, 44 \%$ and $34 \%$ of total emissions for wooden building, insulated concrete building, blockhouse and $\log$ house, respectively. The share of $\mathrm{CO}_{2}$ emission from building materials will increase in future due to declining emissions from power generation. The total $\mathrm{CO}_{2}$ emissions during the construction and operational phase during 50 years are shown in Figure 13.

\section{Conclusions}

This study assessed the investment cost, operational energy cost and corresponding carbon emissions of 12 energy efficient buildings in Kouvola housing fair. Besides, carbon emissions were compared with four different structures, namely wooden building, insulated concrete building, blockhouse and log house. Also, contributions of carbon emissions from building structures and energy use during 50 years were analysed.

According to the Finnish NZEB regulation, all buildings achieved energy certificate class $B$ so that energy performance was close to NZEB limit and houses were insulated as little as the minimum reference U-values allow. An average EP value for 12 buildings was slightly higher than the estimated average EP value at the Tampere 2012 housing fair.

This allows to conclude that energy performance was driven fully by the regulation and seems not to be an issue for house owners. In addition, construction cost had slightly negative correlation to EP value, i.e. more energy efficient houses had a lower cost. This indicates a weak relation between total construction cost and energy performance, as well as that cost and energy efficiency goes hand in hand. More specific cost categories were analyzed in order to find energy performance related additional cost. It was found that EP-value improvement by 40 units increased less than $2 \%$ of construction cost. Moreover, some key factors increasing the unit cost of construction were a building with irregular shape and height, double storied building, floor finishing materials.

The annual contribution of wooden chips, district heating and electricity to the overall delivered energy (weighted average of 12 buildings) were $4 \%, 56 \%$ and $40 \%$, respectively. However, the annual contribution of $\mathrm{CO}_{2}$ emission from wooden chips, district heating and electricity were $4 \%, 9 \%$ and $87 \%$, respectively, due to the high emission factor for electricity and renewable source of district heating.

Wooden buildings were environment-friendly compared to the insulated concrete and blockhouses due to low emission of $\mathrm{CO}_{2}$. Additionally, wooden buildings stored a good amount of carbon. With current specific $\mathrm{CO}_{2}$ emission factors in 50 years life cycle carbon footprint, $\mathrm{CO}_{2}$ emissions of operational energy dominated with about $60 \%$ share over materials'. However, the contribution of material emissions to overall emission will increase due to declining $\mathrm{CO}_{2}$ emissions from power generation in future.

This research was supported by European Union's Horizon 2020 research and innovation programme, NERO project No 754177.

\section{References}

1. M.S. Geraldi and E. Ghisi, Energy \& Buildings, 211, (2020)

2. B.C. Bates, Z.W. Kundzewicz, S. Wu, J.P. Palutikof, Climate change and water (2008)

3. J. Kurnitski, A. Saari, T. Kalamees, M. Vuolle, J. Niemelä, T. Tark, Estonian Journal of Engineering, 19 (2013).

4. Z. Ma, P. Cooper, D. Daly, L. Ledo, Energy \& Buildings, 55 (2012).

5. S.K. Pal, A. Takano, K. Alanne, K. Siren, Building and Environment, 123 (2017)

6. J. Kurnitski, Cost Optimal and Nearly Zero- Energy Buildings (nZEB)- Definitions, Calculation Principles and Case Studies, Springer, 2013.

7. A. Stephan, R.H. Crawford, K. de Myttenaere, Applied Energy, 112 (2013).

8. L. Magnier, F. Haghighat, Building and Environment, 45 (2010)

9. E. Pikas, M. Thalfeldt, J. Kurnitski, R. Liias, Energy, 84 (2015)

10. D. D'Agostino, D. Parker, Energy, 149 (2018)

11. B. Manrique Delgado, S. Cao, A. Hasan, K. Sirén, Energy Conversion and Management, 154, (2017)

12. N. Lolli, S.M. Fufa, M. Kjendseth Wiik, Wood Material Science \& Engineering: Forum Wood Building Nordic, Aalto University, Helsinki, Finland, 14 (2019)

13. A.H. Buchanan, S.B. Levine, Environmental Science and Policy, 2 (1999) 
14. S. Vares, T. Häkkinen, J. Ketomäki, J. Shemeikka, N. Jung, Journal of Building Engineering, 22 (2019).

15. H. Birgisdottir, A. Moncaster, A.H. Wiberg, C. Chae, K. Yokoyama, M. Balouktsi, S. Seo, T. Oka, T. Lützkendorf, T. Malmqvist, Energy and Buildings, 154, (2017)
16. Singiresu S. Rao, Engineering Optimization: Theory and Practice, John Wiley \& Sons, 2019.

17. Talopeli cost database. Available at https://talopeli.fi/. Access date 01.03.2019 